\title{
GENETIC RELATIONSHIP BETWEEN COLD HARDINESS AND GROWTH AT LOW TEMPERATURE IN MEDICAGO SATIVA
}

\author{
HUNOR DADAY \\ Division of Plant Industry, C.S.I.R.O., Canberra, Australia
}

Received 14.x.63

\section{INTRODUCTION}

THE expected response of a quantitative character to artificial selection is a function of heritability, selection intensity, phenotypic standard deviation of the particular metric character concerned, and its genetic correlation with other selected metric characters.

Daday and Greenham (1960) reported that variation in cold hardiness of the root tissues of Medicago sativa L. was due mainly to additive gene effects and preliminary investigation showed that the phenotypic correlation between percentage of uninjured leaves and winter growth was low $(r=0 \cdot 15)$. The variation in the winter growth of $M$. sativa has been shown to be due primarily to additive gene effects (Daday, unpublished).

Levitt (1956) stated that, in general, the rate of growth in autumn is inversely related to frost hardiness, particularly in annuals in the U.S.A. Moreover, it is usually accepted that for ecotypes of other species, there is a positive correlation between winter growth and frost injury. However, as far as the author is aware, there is no critical published work on the genetic relationship between these two variables. This relationship is of economic importance because winter growth of forage plants is seriously limited by extensive cold injury in continental climatic regions, e.g. those of the Tablelands of Australia.

This study deals with the genetic relationship between growth at low temperature and extent of cold injury in $M$. sativa. The procedure has been to study variances, heritabilities and correlation coefficients of these two metrical characters.

The term "cold injury" is used in this paper to indicate frost injury under Australian conditions, i.e. conditions such that the frosts are not severe or prolonged (see table of temperatures at end of Section 2).

\section{MATERIAL AND METHODS}

The varieties used were Hairy Peruvian, African, Hunter River, Du Puits and Rambler (Daday et al., I961). The first two varieties, though cold susceptible, are able to grow under low temperature conditions such as those experienced. Du Puits, a relatively cold-hardy variety, has a very low winter growth rate. Rambler is characterised by marked winter dormancy and cold hardiness. Hunter River is intermediate (Daday and Greenham, 1960).

$F_{1}$ 's were obtained by hand crossing individual plants of the parental varieties, and the $F_{2}$ 's by intercrossing a number of randomly selected $F_{1}$ plants. 


\section{(a) Spaced plant experiment}

The $F_{1}$ and $F_{2}$ families of Hunter River and Rambler varieties were established under spaced plant conditions in October 1958. The plants were grown under field conditions and cut back in early April. They were scored ( $I-6)$ for both winter growth and cold injury at the end of July 1959.

\section{(b) Sward experiment}

In addition to four parental varieties (Hunter River, African, Hairy Peruvian and Du Puits), the $F_{1}$ 's and $F_{2}$ 's from the crosses Du Puits $\times$ Hairy Peruvian and Du Puits $\times$ African were also included in this experiment. Each family was represented by 40 or 60 full-sib plants, in four or six replications of plots of 1o plants each. The plants were in rows $30 \mathrm{~cm}$. apart with $20 \mathrm{~cm}$. between plants. $F_{1}$ experiments were established in June (A) and August (B) 1960 , and $F_{2}$ experiments were established in June (A) and August (B) $196 \mathrm{I}$. The different planting times showed no marked influence on the results. After establishment in the field, plants were harvested periodically until April I, 1962, at which time all plots were cut back. Winter growth was measured from April to the end of July 1962.

Cold-injured leaves and stems were separated from healthy plant material, and after drying, the percentage of injured material was used as a measure of cold injury. The total dry matter content of each plot gave information on yield for each family during the period of low temperature.

Calculation of heritability was based on family means. The expected mean squares and calculation of family heritability are as follows:-

\begin{tabular}{|lc|c|c|c|}
\hline & & M.S. & Exp. M.Sq. & Exp. M. Product \\
\hline & & L & $\sigma_{\mathbf{E}}^{2}+r \sigma_{\mathbf{L}}^{2}$ & $\operatorname{COV}_{\mathbf{E}}+r \operatorname{COV}_{\mathbf{L}}$ \\
\hline $\begin{array}{l}\text { Lines (families) } \\
\text { Replications } \\
\text { Fam. } \times \text { Rep. interaction }\end{array}$ & $:$ & $\mathbf{R}$ & $\sigma_{\mathbf{E}}^{2}$ & $\operatorname{COV}_{\mathbf{E}}$ \\
\hline
\end{tabular}

where $r$ is the number of replications involved, $\sigma_{\mathrm{L}}^{2}$ is the component of variance between families, and $\sigma_{\mathrm{E}}^{2}$ is the family $\times$ replication mean square. These components have been estimated by

$$
\begin{aligned}
\hat{\sigma}_{\mathrm{L}}^{2} & \bumpeq \frac{1}{r}(\mathrm{~L}-\mathrm{E}) \\
\hat{\sigma}_{\mathrm{E}}^{2} & \simeq \mathrm{E} \\
h_{f}^{2} & =\frac{\sigma_{\mathrm{L}}^{2}}{\sigma_{\mathrm{L}}^{2}+\sigma_{\mathrm{E}}^{2}}
\end{aligned}
$$

The correlation coefficients were estimated following Falconer (1960). The phenotypic correlation $\left(r_{\mathbf{P}}\right)$ measures the association between two directly observed characters. The genotypic correlation $\left(r_{\mathrm{A}}\right)$ measures the association between breeding values for the two characters. (Since the variance of both characters was due almost solely to additive gene effects, $r_{A}$ will be used instead of the conventional $r_{G}$.) The environment correlation $\left(r_{E}\right)$ measures the correlation due to environmental and non-additive genetic deviations. 
Average monthly temperatures and day length in Canberra between April and July 1959 and 1962 were:-

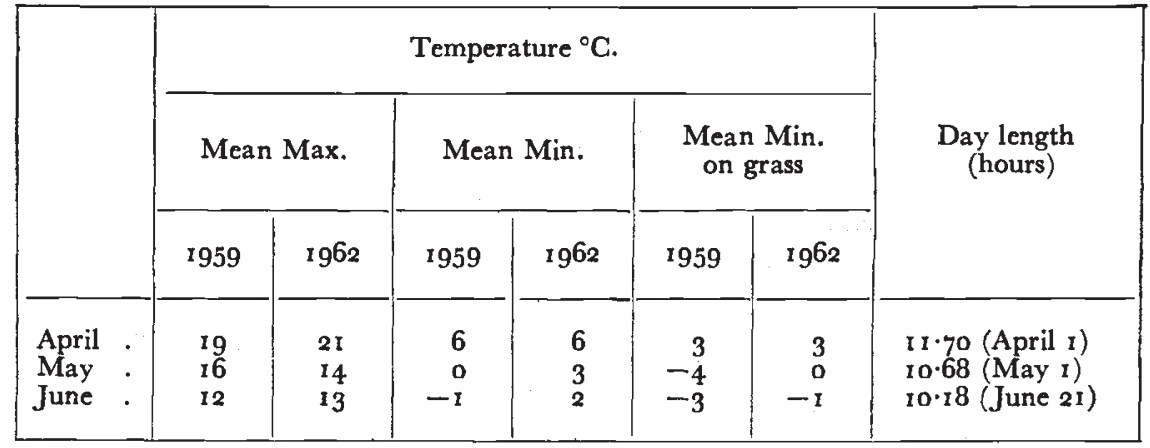

\section{RESULTS}

The relationship between growth at low temperature and the extent of cold injury was investigated under both spaced and sward conditions.

\section{(a) Spaced plant experiment}

The variances and phenotypic correlations of the scorings for winter growth and cold injury of the $F_{1}$ 's and $F_{2}$ 's of Hunter River and Rambler are given in table $\mathrm{I}$.

\section{TABLE I}

Variances and phenotypic correlations of growth at low temperature $(\mathrm{Y})$ and degree of cold injury $(C)$ in $F_{1}$ and $F_{2}$ of $\mathrm{M}$. sativa.

\begin{tabular}{|c|c|c|c|c|c|}
\hline \multicolumn{2}{|r|}{ Generations } & D.F. & $\sigma_{\mathrm{Y}}^{2}$ & $\sigma_{\mathrm{C}}^{2}$ & $r_{\mathbf{P}}$ \\
\hline$F_{1}$ & . & 196 & $0.270 \pm 0.027$ & $0.360 \pm 0.036$ & $0.34^{6}$ \\
\hline$F_{2}$ & - & 164 & $0.672 \pm 0.074$ & $0.639 \pm 0.070$ & 0.031 \\
\hline
\end{tabular}

The differences in both variances, $\sigma_{\mathrm{Y}}^{2}$ and $\sigma_{\mathrm{C}}^{2}$, between $\mathrm{F}_{1}$ and $\mathrm{F}_{2}$ are significant, being 5.09 and 3.54 times their standard errors. These differences indicate an increased genetical segregation in $F_{2}$. The phenotypic correlation shows a positive association between the two metric properties in $F_{1}$, but this association is close to 0 in $F_{2}$, suggesting the independent segregation of these variable.

\section{(b) Sward experiment}

Four parental varieties and certain $F_{1}$ and $F_{2}$ families were included in this experiment, where the relationships between variables were examined both for parental varieties and $F_{1}$ and $F_{2}$ families. Particular attention was given to heritability, and phenotypic, genotypic and environmental correlations. 
The mean dry matter of varieties in the experiments $F_{1} A$ and $F_{2} B$, varies between 47 and $115 \mathrm{gm}$., and 44 and $189 \mathrm{gm}$., while the percentage cold injury of varieties is between 31 and 80 per cent. and 19 and 62 per cent. respectively. The analyses of variance show significant differences $\left(\mathrm{P}<\mathrm{O}^{\cdot} .00 \mathrm{I}\right)$ among varieties for both dry matter

TABLE 2

Analyses of variances and covariances of dry matter production $(\mathrm{gm} . / \mathrm{plot})$ and percentage cold injury within $F_{1}$ and $F_{2}$ populations of $\mathrm{M}$. sativa

\begin{tabular}{|c|c|c|c|c|c|}
\hline \multirow{2}{*}{\multicolumn{2}{|c|}{ Variances }} & \multirow{2}{*}{ D.F. } & \multicolumn{2}{|c|}{ Mean squares } & \multirow{2}{*}{$\begin{array}{c}\text { Mean } \\
\text { cross-products }\end{array}$} \\
\hline & & & Dry matter & Cold injury & \\
\hline \multicolumn{6}{|c|}{$F_{1} A$} \\
\hline $\begin{array}{l}\text { Families } \\
\text { Replications } \\
\text { Residual }\end{array}$ & : & $\begin{array}{r}10 \\
5 \\
50\end{array}$ & $\begin{array}{l}7059^{* * *} \\
2827^{*} \\
900\end{array}$ & $\begin{array}{l}\text { IIII *** } \\
\text { I48 } \\
239\end{array}$ & $\begin{array}{l}-122 \\
-510 \\
-47\end{array}$ \\
\hline \multicolumn{6}{|c|}{$F_{1} B$} \\
\hline $\begin{array}{l}\text { Families } \\
\text { Replications } \\
\text { Residual }\end{array}$ & : & $\begin{array}{r}31 \\
3 \\
93\end{array}$ & $\begin{array}{l}3^{168 * * *} \\
959 \\
995\end{array}$ & $\begin{array}{l}668 * * * \\
1015^{* * * *} \\
13^{1}\end{array}$ & $\begin{array}{r}-189 \\
891 \\
-98\end{array}$ \\
\hline \multicolumn{6}{|c|}{$\mathrm{F}_{2} \mathrm{~A}$} \\
\hline $\begin{array}{l}\text { Families } \\
\text { Replications } \\
\text { Residual }\end{array}$ & $\dot{5}$ & $\begin{array}{r}16 \\
5 \\
80\end{array}$ & $\begin{array}{l}5194^{* * *} \\
2365 \\
1549\end{array}$ & $\begin{array}{l}65^{* * *} \\
219 \\
118\end{array}$ & $\begin{array}{r}-162 \\
-215 \\
-45\end{array}$ \\
\hline \multicolumn{6}{|c|}{$\mathrm{F}_{2} \mathrm{~B}$} \\
\hline $\begin{array}{l}\text { Families } \\
\text { Replications } \\
\text { Residual }\end{array}$ & : & $\begin{array}{r}14 \\
5 \\
70\end{array}$ & $\begin{array}{c}11478 * * \\
7753 \\
3790\end{array}$ & $\begin{array}{c}745^{* * *} \\
84 \\
83\end{array}$ & $\begin{array}{l}163 \\
437 \\
-3\end{array}$ \\
\hline
\end{tabular}

(V.R. $=17.92$ and V.R. $=33.21$ ) and cold injury (V.R. $=20.96$ and V.R. $\left.=51^{1} \cdot \mathrm{IO}\right)$. The critical V.R. is 9.34 for $n_{1}=3, n_{2}=15$, $\mathrm{P}=0.001$. The phenotypic $\left(r_{\mathrm{P}}\right)$ and genotypic $\left(r_{\mathrm{A}}\right)$ correlation coefficients of parental varieties are 0.50 , and 0.76 in $\mathrm{F}_{1} \mathrm{~A}$ and 0.76 , and 0.93 in $\mathrm{F}_{2} \mathrm{~B}$. Both $r_{\mathrm{P}}$ and $r_{\mathrm{A}}$ are positive and high, which means that increasing dry matter production will be associated with a greater incidence of cold injury.

In view of this high positive correlation between the two variables, the magnitude of the heritabilities and the genetic correlations were 
calculated in $F_{1}$ and $F_{2}$ populations, this information being used to determine whether pleiotropic gene action or independent ecotypic selection is responsible for the high positive correlation between the characters in the parental varieties.

The an alyses of variances and covariances of dry matter (gm./plot) and cold injury percentage of $F_{1}$ and $F_{2}$ are presented in table 2.

The differences between families are highly significant in all analyses. The mean dry matter production in experiments $F_{1} A, B$ and $F_{2} A, B$ varies between $8 \mathrm{I}$ and $I 73$ gm., 54 and $I 77 \mathrm{gm}$.; 60 and I63 gm., and 92 and $279 \mathrm{gm}$.; while the cold injury is between 28 and 66 per cent., 22 and 67 per cent., and 6 and 45 per cent., and 9 and 46 per cent. respectively. The measures of between family heritability of the two metric characters are shown in table 3 .

TABLE 3

Heritability of family means for dry matter and cold injury in $F_{1}$ and $F_{2}$ of $\mathrm{M}$. sativa

\begin{tabular}{|c|c|c|c|c|c|}
\hline \multirow{2}{*}{$\begin{array}{c}\text { Generation } \\
\text { and experiments }\end{array}$} & \multirow{2}{*}{ Rep. No. } & \multicolumn{2}{|c|}{$\begin{array}{c}\text { Based on } \\
\text { family means }\end{array}$} & \multicolumn{2}{|c|}{$\begin{array}{l}\text { Based on single } \\
\text { plot values }\end{array}$} \\
\hline & & $\begin{array}{c}\text { Dry } \\
\text { matter }\end{array}$ & $\begin{array}{l}\text { Cold } \\
\text { injury }\end{array}$ & $\underset{\text { matter }}{\text { Dry }}$ & $\begin{array}{l}\text { Cold } \\
\text { injury }\end{array}$ \\
\hline $\mathrm{F}_{1} \underset{\mathrm{B}}{\mathrm{A}}$ & $\begin{array}{l}6 \\
4\end{array}$ & $\begin{array}{l}0.87 \\
0.90\end{array}$ & $\begin{array}{l}0.78 \\
0.80\end{array}$ & $\begin{array}{l}0.53 \\
0.39\end{array}$ & $\begin{array}{l}0.3^{8} \\
0 \cdot 5^{1}\end{array}$ \\
\hline $\mathrm{F}_{2} \underset{\mathrm{B}}{\mathrm{A}}$. & $\begin{array}{l}6 \\
6\end{array}$ & $\begin{array}{l}0.70 \\
0.67\end{array}$ & $\begin{array}{l}0.82 \\
0.89\end{array}$ & $\begin{array}{l}0 \cdot 28 \\
0 \cdot 25\end{array}$ & $\begin{array}{l}0.43 \\
0.57\end{array}$ \\
\hline
\end{tabular}

The heritabilities based on family means vary between 0.67 and 0.90 and the heritabilities based on single plot values range between 0.25 and 0.57 . These figures indicate the presence of a considerable amount of genetic variance between families in the $F_{1}$ and $F_{2}$ generations. Therefore, response to family selection should show a marked advance in the two characters.

The phenotypic $\left(r_{\mathbf{P}}\right)$, genotypic $\left(r_{\mathbf{A}}\right)$ and environmental $\left(r_{\mathrm{E}}\right)$ correlation coefficients for individual plot performance in the $F_{1}$ and $F_{2}$ were calculated from analyses of variances and covariances and results presented in table 4 .

The correlation coefficients $r_{\mathrm{P}}, r_{\mathrm{A}}$ and $r_{\mathrm{E}}$ are uniformly low in $\mathrm{F}_{2}$, under sward and the $r_{\mathrm{P}}$ under single plant conditions. The phenotypic correlations differ in $F_{1}$. Positive association was found between the variables in $F_{1}$ under single plant conditions, but negative association in $F_{1}$ under sward conditions. These results indicate that the positive correlation of these metrical characters in the parental varieties was not due to pleiotropy or close linkage, but probably arose from independent response to natural selection. The low correlation coefficients 
TABLE 4

Phenotypic $\left(r_{\mathbf{P}}\right)$, genotypic $\left(\tau_{\mathrm{A}}\right)$ and environment $\left(\tau_{\mathrm{E}}\right)$ correlation coefficients between dry matter production and cold injury in $F_{1}$ and $F_{2}$ of $\mathrm{M}$. sativa

\begin{tabular}{|c|c|c|c|c|c|}
\hline \multicolumn{2}{|c|}{$\begin{array}{c}\text { Generation and } \\
\text { experiment }\end{array}$} & $r_{\mathrm{P}}$ & $r_{\mathrm{A}}$ & $r_{\mathrm{E}}$ \\
\hline $\mathrm{F}_{1} \cdot$ & $\cdot$ & $\mathrm{A}$ & $\begin{array}{r}-0.069 \\
-0 \cdot 190\end{array}$ & $\begin{array}{r}-0.032 \\
-0.084\end{array}$ & $\begin{array}{r}-0 \cdot 101 \\
-0.273\end{array}$ \\
\hline $\mathrm{F}_{2} \cdot$. & $\mathrm{B}$ & $\mathrm{A}$ & $\begin{array}{r}-0.097 \\
0.025\end{array}$ & $\begin{array}{r}-0.084 \\
0.074\end{array}$ & $\begin{array}{l}-0.106 \\
-0.001\end{array}$ \\
\hline
\end{tabular}

also indicate the occurrence of a high frequency of recombination, suggesting that cold hardiness of leaves and stems can be combined with high growth rates at low temperatures (figs. I and 2), under similar climatic conditions to the one described in the present experiment.

\section{DISCUSSION}

The present investigation discloses high genetical potentialities for response to selection in both metric characters in $M$. sativa.

Knowledge of phenotypic, genotypic and environmental correlations is of great value to breeders, since the phenotypic correlation alone does not provide the complete information for prediction of response to selection. Dickerson (1955) found the phenotypic correlation between egg production and egg weight to be low $(r=-0 \cdot 04)$, but the genotypic correlation coefficient was -0.39 and both metric characters were affected by common environmental factors $r_{E}=$ $(+0 \cdot 25)$.

The genetic correlation coefficient is high and positive for cold injury and winter growth among the parental varieties, but the coefficients in the $F_{2}$ generations are close to zero and indicate that the positive correlation among parental varieties is simply the result of independent ecotypic selection for the two characters, neither pleiotropy nor linkage being involved. In view of this low correlation coefficient and the high heritability, new combinations of cold hardiness and winter growth may be expected.

Furthermore, as a result of genetic segregation, new recombinations exist which not only combine cold hardiness and winter growth, but also show both characters with a greater phenotypic expression than either of the parental genotypes.

Thus in spite of the early belief to the contrary, cold hardiness and winter growth have been combined, and marked responses to selection may be anticipated under climatic conditions similar to those of Canberra. Most rapid improvement is to be expected from selection applied simultaneously to both variables. 


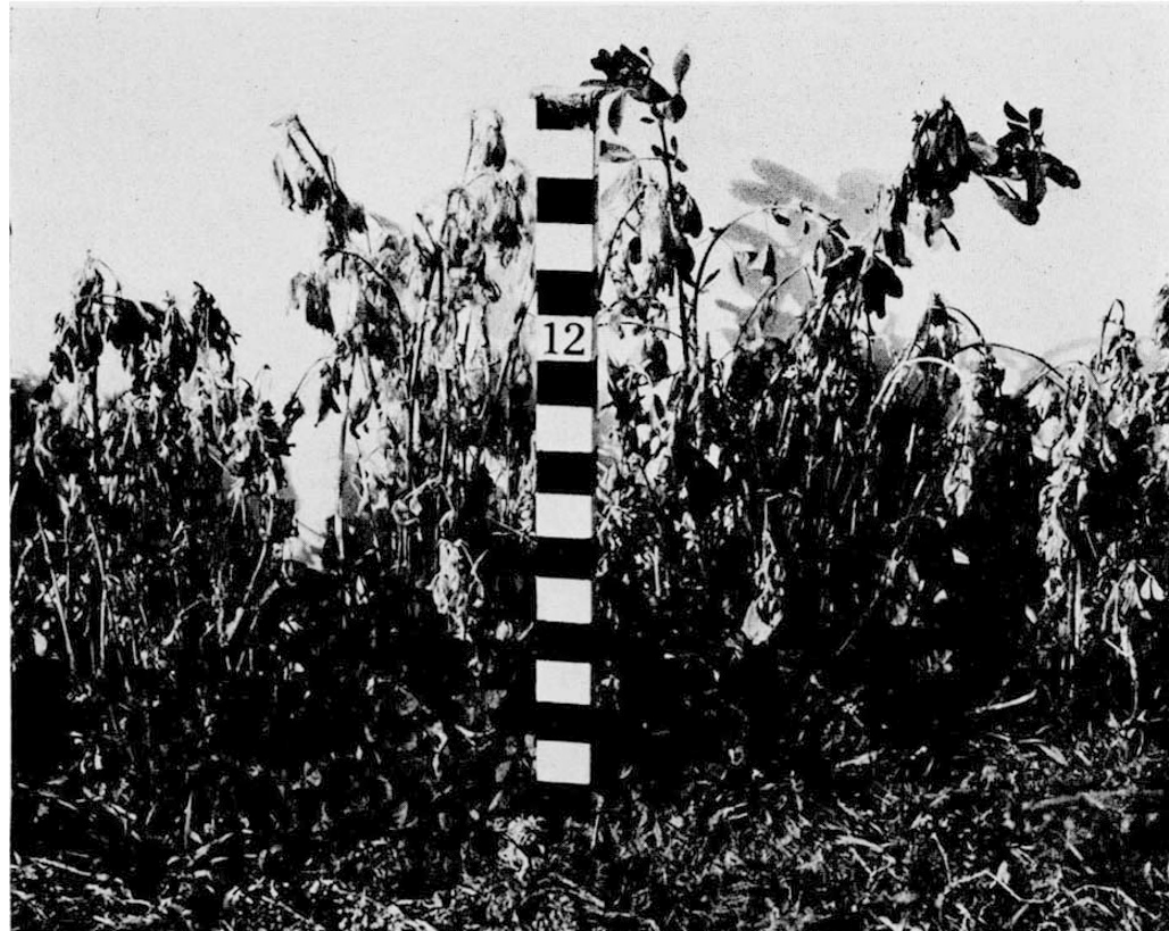

Fig. 1.- Hairy Peruvian variety; growth under low tempcrature, associated with high degree of cold susceptibility. Plants grown under field conditions, including exposure to frost.

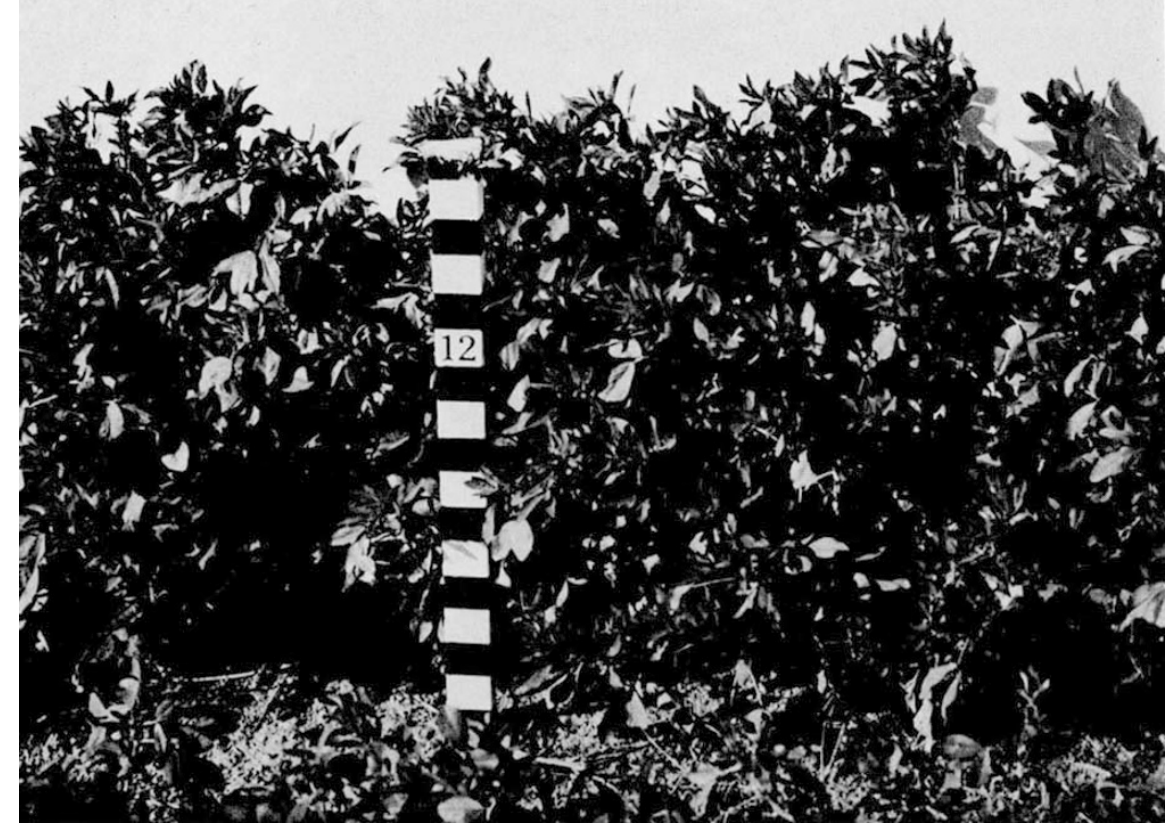

Fig. 2.- $F_{2}$ plants of Hairy Peruvian $\times$ Du Puits; growth under low temperature, associated with high degree of cold resistance. Grown under the same conditions as the plants in fig 1 . 


\section{SUMMARY}

I. The genetic relationship between growth at low temperatures and susceptibility to cold injury was investigated in parental varieties, and their $F_{1}$ and $F_{2}$ of $M$. sativa.

2. High and positive correlation coefficients were found between parental varieties.

3. The phenotypic variances of growth at low temperature and cold injury were significantly greater in $F_{2}$ than in $F_{1}$, under single plant conditions.

4. The heritabilities of both characters were high $(0.25-0.57)$ in $F_{1}$ and $F_{2}$.

5. The phenotypic, genotypic and environmental correlation coefficients were very close to zero in $F_{2}$.

6 . The positive correlation coefficients between cold injury and growth at low temperature is interpreted as an independent response to natural selection in the parental varieties.

7. Cold resistance has been combined with growth at low temperatures and a rapid response to selection may be expected on the basis of this investigation.

Acknowledgments.-I am greatly indebted to Dr B. D. H. Latter for his helpful suggestions in the statistical analysis. I would also like to thank Messrs G. Krygier, R. F. Baye and L. J. Hopkins for their able technical assistance during the course of the experiments.

\section{REFERENCES}

DADAY, H., AND GREENHAM, C. G. 196o. Genetic studies on cold hardiness in Medicago sativa L. J. Hered., 5I, 249-255.

DAdAy, H., MOtTershead, B. E., AND ROGERS, V. E. $196 \mathrm{I}$. Performance and interactions in varieties of lucerne (Medicago sativa L.). Aust. F. Exp. Agric. Anim. Husb., $r, 67-72$.

DICKERSON, G. E. 1955. Genetic slippage in response to selection for multiple objectives. Cold. Spr. Harb. Symp. quant. Biol., 20, 21 3-224.

FAlCONER, D. S. 196o. Introduction to quantitative genetics. Oliver and Boyd, Edinburgh and London.

Levitt, J. 1956. The hardiness of plants. Academic Press Inc., New York, N.Y. 